\title{
SEROLOGICAL TEST'S.
}

\section{ON THE PERSISTENCE OF PRECIPITINS IN SERA STOREI) IN VITRO.}

II. ON THE REACTIONS OBTAINED WITH (a) COMPLEMENT FIXATION TESTS AND (b) PRECIPITIN TESTS, WITH THE GUT CONTENTS OF BLOOD-SUCKING ARTHROPODS.

\author{
By LAJOS GÓZONY, M.D., EDWARD HINDLE, Ph.D., \\ AND PHILIP H. ROSS, M.R.C.S., L.R.C.P.
}

\section{(From the Quick Laboratory, Cambridge.)}

I. The persistence of precipitins in vitro.

VARIOUS authors have noted that antisera sealed in glass tubes may preserve their properties for considerable periods. Thus Nuttall (1904) found that definite reactions could be obtained with antisera that had been kept for fourteen months, and it seemed probable that reactions could be obtained with much older antisera.

During his experiments Prof. Nuttall prepared many kinds of antisera by injecting rabbits with the blood or serum of different species of animals. These antisera, and also their homologous bloods, were stored in sealed glass tubes, and have been kept together in a dark case in the laboratory, at a temperature of about $15^{\circ} \mathrm{C}$. Some of the bloods, moreover, were preserved dried on filter paper. Prof. Nuttall kindly placed this material at our disposal and suggested that it would be of interest to determine whether the antisera still preserved their properties.

The results are given in detail in Table $I$ and it will be noted that in two cases well-marked specific reactions were obtained. In others, however, the antisera also reacted with related species, whilst occasionally somewhat anomalous results were obtained. Thus hyaena antiserum gave a distinct precipitum with dog blood as well as hyaena, and a slight precipitum with blood from a Ross seal. Similarly dog 
antisera reacted with raccoon, as well as dog blood; and Mexican deer antiserum with Mexican deer, antelope, wild sheep, and goat blood. Specific reactions were obtained only with ourang-outang antiserum, prepared 17. XI. 1902, and hippopotamus antiserum, prepared 11. III. 1903. On the other hand the following antisera gave entirely negative reactions : man, ox, cat, llama, seal, and hedgehog.

The tests were made with 1 to 100 dilutions of the antigens. To 0.5 c.c. of each dilution was added 0.05 c.c. of the antiserum.

II. The reactions obtained with (a) Complement fixation tests and (b) Precipitin tests, on the gut contents of blood-sucking arthropods.

It is well known that the properties of the precipitinogen (blood albuminoids), in the dried state, may be preserved for years and still give specific reactions, but it has been found that in the process of digestion in vertebrates, the properties are rapidly lost. On the other hand, in blood-sucking arthropods digestion proceeds much more slowly, and it has been found possible, by means of the precipitin test, to recognise the species of animal on which they have been feeding. Having a number of ticks in the laboratory, that had been starved for periods varying up to two years, it was decided to examine their gut contents by the complement fixation and precipitation tests.

\section{(a) Complenient fixation tests.}

The following technique has been employed for these experiments.

The haemolysin ${ }^{1}$ was tested by mixing varying amounts $(1$ c.c. of a $1: 100,1: 200$ : $1: 400$ dilution) with 1 c.c. of a $5 \%$ emulsion of red blood corpuscles of sheep, and 1 c.c. of a $1: 10$ dilution of guinea-pig serum (as complement). The mixture was then made up to 5 c.c. by adding $0.9 \%$ salt solution and placed for one hour in a thermostat at $37^{\circ} \mathrm{C}$. Complete haemolysis was obtained with 1 c.c. of a $1: 300$ dilution of the haemolysin.

The following is an example of one of the tests:

\begin{tabular}{|c|c|c|c|c|c|c|}
\hline Haemolysin & $\begin{array}{c}1 \text { c.c. } \\
\text { (1:50 dilution) }\end{array}$ & $\begin{array}{c}1 \text { c.c. } \\
(1: 100)\end{array}$ & $\begin{array}{c}1 \text { c.c. } \\
(1: 200)\end{array}$ & $\begin{array}{c}1 \text { c.c. } \\
(1: 300)\end{array}$ & $\begin{array}{c}1 \text { c.c. } \\
(1: 400)\end{array}$ & $\begin{array}{c}1 \text { c.c. } \\
(1: 800)\end{array}$ \\
\hline $\begin{array}{l}\text { Complement } \\
\text { (1:10 dilution) }\end{array}$ & 1 c.c. & 1 c.c. & 1 c.c. & 1 c.c. & 1 c.c. & 1 c.c. \\
\hline $\begin{array}{l}5 \% \text { sheep red } \\
\text { blood corpuscles }\end{array}$ & 1 c.c. & 1 c.c. & 1 c.c. & 1 c.c. & 1 c.c. & 1 c.c. \\
\hline $\begin{array}{l}0.9 \% \mathrm{NaCl} \text { sol. } \\
\text { Haemolysis }\end{array}$ & $\begin{array}{c}2 \text { c.c. } \\
\text { Complete }\end{array}$ & $\begin{array}{c}2 \text { c.c. } \\
\text { Complete }\end{array}$ & $\begin{array}{c}2 \text { c.c. } \\
\text { Complete }\end{array}$ & $\begin{array}{c}2 \text { c.c. } \\
\text { Complete }\end{array}$ & $\begin{array}{c}2 \text { c.c. } \\
\text { Partial }\end{array}$ & $\begin{array}{c}2 \text { c.c. } \\
\text { Absent }\end{array}$ \\
\hline
\end{tabular}



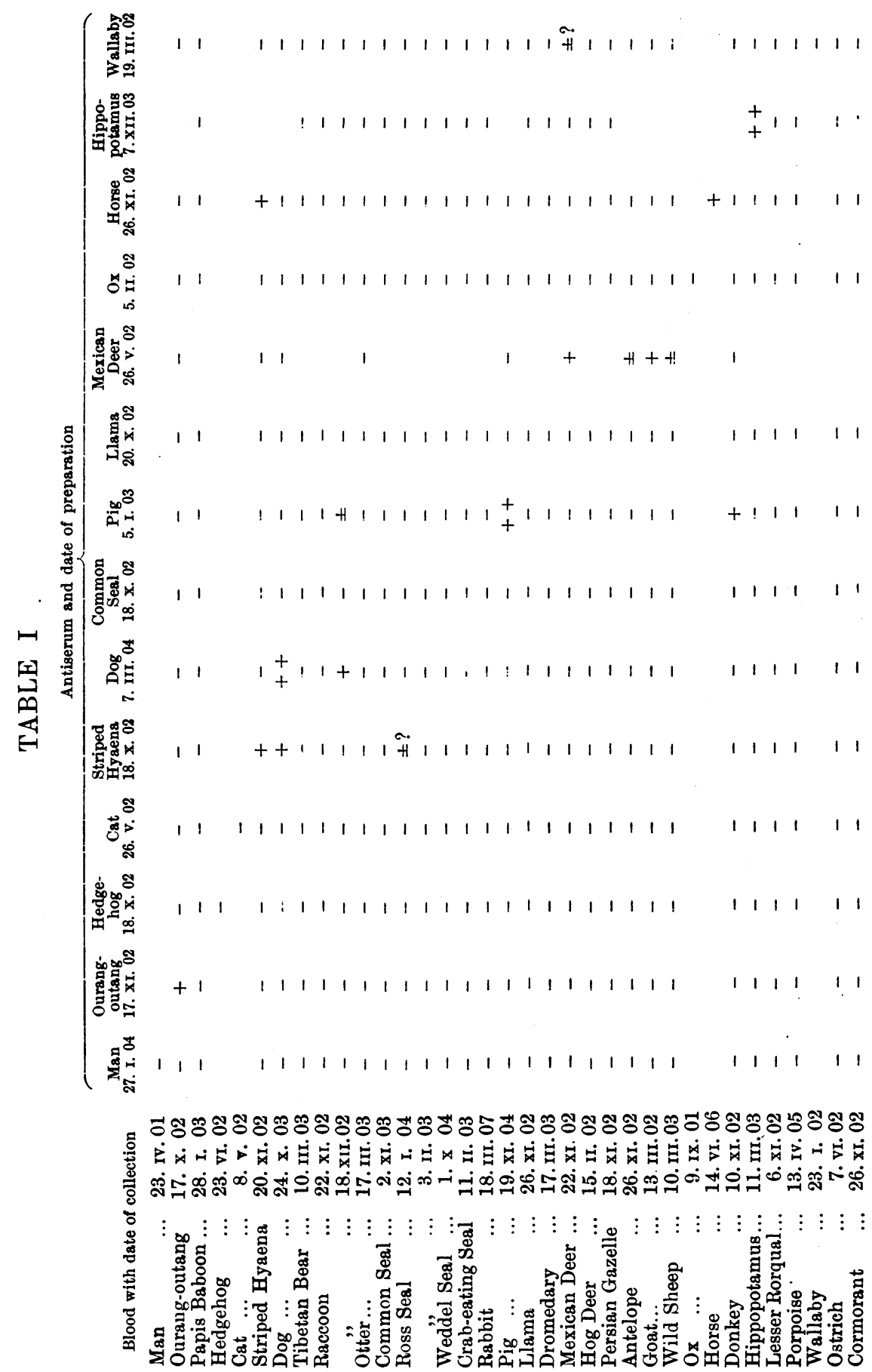
When making a reaction two or three times as much haemolysin was employed as was necessary to cause complete haemolysis. The haemolysin was only tested once every two or three weeks, as it changes very slowly, but the complement had to be tested before each experiment.

The complement was tested in a similar manner to the haemolysin, employing varying amounts of complement and a fixed amount of haemolysin, as shown in the following table:

\begin{tabular}{|c|c|c|c|c|c|c|}
\hline $\begin{array}{l}\text { Complement } \\
\text { (1:10 dilution) }\end{array}$ & 0.2 c.c. & 0.4 c.c. & 0.6 c.c. & 0.8 c.c. & 1.0 c.c. & $1 \cdot 2$ c.c. \\
\hline $\begin{array}{l}\text { Haemolysin } \\
\text { (1:100 dilution })\end{array}$ & 1 c.c. & 1 c.c. & 1 c.c. & 1 c.c. & 1 c.c. & 1 c.c. \\
\hline $\begin{array}{l}5 \% \text { sheep r.b.c. } \\
0.9 \% \mathrm{NaCl} \text { sol. } \\
\text { Haemolysis }\end{array}$ & $\begin{array}{l}1 \text { c.c. } \\
2 \cdot 8 \text { c.c. } \\
\text { Absent }\end{array}$ & $\begin{array}{l}1 \text { c.c. } \\
2 \cdot 6 \text { c.c. } \\
\text { Partial }\end{array}$ & $\begin{array}{l}1 \text { c.c. } \\
2 \cdot 4 \text { c.c. } \\
\text { Complete }\end{array}$ & $\begin{array}{l}1 \text { c.c. } \\
2 \cdot 2 \text { c.c. } \\
\text { Complete }\end{array}$ & $\begin{array}{l}1 \text { c.c. } \\
2 \cdot 0 \text { c.c. } \\
\text { Complete }\end{array}$ & $\begin{array}{l}1 \text { c.c. } \\
1 \cdot 8 \text { c.c. } \\
\text { Complete }\end{array}$ \\
\hline
\end{tabular}

As in the case of the haemolysin, we always employed two or three times as much complement as was required to bring about complete haemolysis.

Since the serum containing anti-bodies, or the substance which contains the antigen, is able of itself to fix complement in larger or smaller amounts (non-specific fixation), before testing it is necessary to determine the largest quantity of these which alone will not fix complement. For the test half this quantity was employed. The following table is an example of such a test:

$\begin{array}{llllll}\text { Anti-fowl }{ }^{1} \text { serum } & 0.04 \text { c.c. } & 0.06 \text { c.c. } & 0.1 \text { c.c. } & 0.2 \text { c.c. } & 0.4 \text { c.c. } \\ \begin{array}{c}\text { Complement } \\ (1: 10 \text { dilution })\end{array} & 1 \text { c.c. } & 1 \text { c.c. } & 1 \text { c.c. } & 1 \text { c.c. } & 1 \text { c.c. } \\ 0.9 \% \mathrm{NaCl} \text { sol. } & 1.96 \text { c.c. } & 1.94 \text { c.c. } & 1.9 \text { c.c. } & 1.8 \text { c.c. } & 1.6 \text { c.c. }\end{array}$

These mixtures are placed for one hour in a thermostat at $37^{\circ} \mathrm{C}$. and the following then added:

$\begin{array}{llllll}5 \% \text { sheep r.b.c. } & 1 \text { c.c. } & 1 \text { c.c. } & 1 \text { c.c. } & 1 \text { c.c. } & 1 \text { c.c. } \\ \begin{array}{c}\text { Haemolysin } \\ (1: 100 \text { dilution })\end{array} & 1 \text { c.c. } & 1 \text { c.c. } & 1 \text { c.c. } & 1 \text { c.c. } & 1 \text { c.c. } \\ \text { Haemolysis } & \text { Complete } & \text { Complete } & \text { Complete } & \text { Absent } & \text { Absent }\end{array}$

Having by these preliminary examinations determined the appropriate amounts of haemolysin, complement and anti-body, we were then in a position to carry out our experiments. The gut contents of the following arthropods were examined:

1 Inactivated by heating to $56^{\circ} \mathrm{C}$. for half an hour. 
(1) Argas persicus fed on fowl 5 days previously (kept at $30^{\circ} \mathrm{C}$.).

(2) , , , , 1 month ,, ( , ).

(3) , , , , 4 months ,, ( , , ).

(4) $, \quad, \quad, \quad 11 \frac{1}{2},, \quad,, \quad(\quad,$,$) ).$

(5) $\quad, \quad, \quad, 23 \quad, \quad,, \quad$ (kept at $10^{\circ}$ C.).

(6) Ornithodorus moubata fed on fowl 12 months previously (kept at $30^{\circ} \mathrm{C}$.).

(7) , , , $12,$, , and also fed on mouse 6 months previously (kept at $30^{\circ} \mathrm{C}$.).

(8) Pediculus vestimenti fed on man 3 days previously (kept at $30^{\circ} \mathrm{C}$.).

In all these cases total fixation of the complement (no haemolysis) was obtained with the corresponding antisera, whilst invariably in the controls haemolysis was complete.

The following is an example of one of our experiments :

\begin{tabular}{|c|c|c|c|c|c|c|}
\hline $\begin{array}{l}\text { Extract of Argas fed on } \\
\text { fowl } 11 \text { months pre- } \\
\text { viously }\end{array}$ & 0.2 c.c. & $0 \cdot 4$ c.c. & $0 \cdot 2$ c.c. & $0 \cdot 4$ c.c. & $0 \cdot 2$ c.c. & $0 \cdot 4$ c.c. \\
\hline Anti-human serum & - & - & 0.05 c.c. & 0.05 c.c. & - & - \\
\hline Anti.fowl serum & - & - & - & - & 0.05 c.c. & 0.05 c.c. \\
\hline $\begin{array}{l}\text { Complement } \\
\text { (1:10 dilution) }\end{array}$ & 1 c.c. & 1 c.c. & 1 c.c. & 1 c.c. & 1 c.c. & 1 c.c. \\
\hline $0.9 \% \mathrm{NaCl}$ solution & 1.8 c.c. & $1 \cdot 6$ c.c. & 1.75 c.c. & 1.55 c.c. & 1.75 c.c. & 1.55 c.c. \\
\hline \multicolumn{7}{|c|}{ Placed for one hour at $37^{\circ} \mathrm{C}$. and then added: } \\
\hline $5 \%$ sheep r.b.c. & 1 c.c. & 1 c.c. & 1 c.c. & 1 c.c. & 1 c.c. & 1 c.c. \\
\hline $\begin{array}{l}\text { Haemolysin } \\
\text { (1:100 dilution) }\end{array}$ & 1 c.c. & 1 c.c. & 1 c.e. & 1 c.c. & 1 c.c. & 1 c.c. \\
\hline Haemolysis & Complete & Complete & Complete & Complete & Absent & Absent \\
\hline
\end{tabular}

\section{(b) Precipitin tests.}

Having obtained positive results with the complement fixation method in every case, we decided to try also the precipitin test, using as fowl antiserum one which was able to produce a precipitum with a 1:32000 dilution of fowl serum, and as human antiserum one which produced a precipitum with a $1: 30000$ dilution of its corresponding antigen.

In every case after standing for ten minutes a well-marked cloud appeared, and after 24 hours a distinct precipitum, the controls being negative.

From the results of these two series of experiments it is obvious, therefore, that the process of digestion takes place extremely slowly in ticks, and that the digestive fluids do not affect the albuminoid substances which give complement fixation and precipitin reactions. As might be expected a mixture of bloods inside the gut of the tick does not affect the reactions, for Ornithodorus moubata that had been 
fed on a fowl and subsequently on a mouse gave as definite reactions as other ticks which had been fed only on fowls. In Pediculus vestimenti the digestion of the blood takes place much more rapidly than in ticks, but well-marked reactions were obtained in the case of lice that had been fed three days previously. At a temperature of $30^{\circ} \mathrm{C}$. these insects could not endure starvation for any longer period.

The results of both series of experiments seemed to be so surprising as to be worth recording. The methods we have employed may be applied practically in the identification of the sources of food of bloodsucking arthropods. The preservation of the properties of blood for as long as 23 months in the gut of a tick raises an interesting question in physiology.

\section{SUMMARY OF RESULTS.}

1. Sera and antisera when kept in the dark at room temperature sealed in glass tubes occasionally give specific reactions after a period of 12 years. In most cases, however, negative results were obtained with the antisera, whilst in others the reactions were non-specific.

2. Fowl blood will still give specific complement fixation and precipitin reactions after being in the alimentary canal of either Argas persicus or Ornithodorus moubata for at least 23 months. The gut contents of Pediculus vestimenti fed on man three days previously, also will give specific reactions with human antisera.

Note. The human and fowl antisera used in the second series of experiments were obtained from the Bacteriological Department of the University of Budapest. The sheep red blood corpuscles were isolated from blood purchased at the slaughter-house, whilst the complement was obtained by killing a guinea-pig and taking the blood from its beart. The haemolysin was purchased.

\section{REFERENCE.}

Nuttall, G. H. F. (1904). Blood Immunity and Blood Relationship.-Precipitin Tests. Cambridge University Press, $444 \mathrm{pp}$. 